JAKUB ISAŃSKI

\title{
MIGRACJE W KSZTAETOWANIU KRAJOBRAZU SPOŁECZNEGO POLSKICH MIAST
}

\begin{abstract}
Isański Jakub, Migracje w kształtowaniu krajobrazu społecznego polskich miast [Migration in shaping the social landscape of Polish cities] edited by J. Kubera, Ł. Skoczylas - "Człowiek i Społeczeństwo", vol. XXXVII, Poznań 2014, pp. 115-124, Adam Mickiewicz University Press. ISBN 978-83232-2764-9. ISSN 0239-3271.
\end{abstract}

Probably never before in history have Poles had so many possibilities of social mobility as today. The destinations of most of those who decide to start their migration within the country are confined to the largest urban areas usually. Their motivation is usually a desire to improve the quality of their life, and that means to try to find a better place to live and work. Urban areas attract people with the promise of finding a job, or better lifestyle, as well as educational opportunities. In carrying out their intentions, migrants contribute to the growth of the urban population (de facto preventing them from depopulation), economic development and cultural heritage. This text is an attempt to look at the phenomenon of migration in recent years and its impact on the transformation of the social landscape of Polish cities.

Jakub Isański, Uniwersytet im. Adama Mickiewicza w Poznaniu, Instytut Socjologii, ul. Szamarzewskiego 89c, 60-568 Poznań, Poland.

\section{WSTĘP}

Prawdopodobnie nigdy wcześniej w historii Polacy nie mieli tak dużych możliwości przemieszczania się jak obecnie. Jeśli decyzja o migracji dotyczy poruszania się w obrębie kraju, zazwyczaj ogranicza się do największych miast. Motywacją jest wówczas najczęściej chęć polepszenia warunków życia, która popycha do podejmowania prób znalezienia lepszego miejsca pracy i zamieszkania. Miasta przyciągają ludzi obietnicą znalezienia zatrudnienia, ofertą kulturalną czy dostępnymi uczelniami. Realizując swoje zamierzenia, migranci przyczyniają się do wzrostu demograficznego miast (de facto zapobiegając ich depopulacji), rozwoju ekonomicznego i kulturowego. Migracje wewnątrzkrajowe są często wstępem do migracji o zasięgu międzynarodowym, dając aktywnym i zazwyczaj młodym ludziom okazję 
do zdobycia potrzebnych środków, wiedzy i kontaktów społecznych. Niniejszy tekst jest próbą przyjrzenia się zjawisku migracji w ostatnich latach i ich wpływowi na przemiany krajobrazu społecznego polskich miast.

\section{MIASTA JAKO CENTRA ROZWOJU}

Socjologiczna refleksja nad rolą miast i ich rozwoju w szerszej analizie dotyczącej przemian społecznych i powstawania nowego typu społeczeństwa ma długą historię. Przyspieszona urbanizacja i masowe migracje ludzi zapoczątkowały, najpierw na zachodzie Europy, a potem także w innych częściach świata, wiele społecznych przemian. Rozwijające się miasta dawały ludziom możliwości znalezienia lepszej pracy (albo przynajmniej takie było społeczne oczekiwanie), z drugiej zaś strony stawiały przed nimi liczne nowe wymagania związane $z$ nowymi regułami życia. W efekcie powstawały zręby zupełnie nowych form życia społecznego związanego z rozwijającymi się miastami - o mentalności mieszkańców XIX-wiecznego miasta pisał na przykład Georg Simmel (2005), o związanych z zamieszkiwaniem na terenach zurbanizowanych stylach życia Louis Wirth (1927), a o wspólnych cechach osobowości ludzi żyjących w czasach zdominowanych przez rozwój społeczny warunkowany rozwojem dużych miast David Riesman (por. Riesman, Glazer, Denney 1996). Wszyscy oni zwracali uwagę na nowe możliwości, jakie otwierały się przed tymi, którzy decydowali się na zmianę miejsca swojego zamieszkania i, uwolnieni od dotychczasowych zobowiązań, szukali własnej drogi rozwoju. Pod pewnymi względami pierwsza dekada XXI wieku jest podobna do sytuacji z początków ery przemysłowej - rozwój gospodarczy stworzył zapotrzebowanie na nowe zawody i specjalizacje, dając ludziom nadzieję na poprawę losu, bogactwo i możliwości indywidualnego rozwoju, pod warunkiem migracji w stronę jednego z dużych ośrodków miejskich.

Aspektem rozwoju miast i obszarów zurbanizowanych, któremu chciałbym się przyjrzeć bliżej, jest, oparta na ogólnych założeniach teorii kapitału społecznego, zdolność do przyciągania ludzi związana z miejskim stylem życia. Amerykański socjolog Robert Putnam, realizując badania terenowe we Włoszech, zauważył znaczenie więzi społecznych w kształtowaniu środowiska sąsiedzkiego. Relacjonując swoje badania, opisał różnice w stopniu sformalizowania kontaktów społecznych. Zwrócił uwagę na znaczenie więzi społecznych oraz dokonującą się współcześnie na tym polu zmianę - zarówno dotyczącą rodzaju więzi, jak i ich roli w życiu społecznym. Kontynuujący w swoich badaniach te wątki Richard Florida, pogłębiając tę analizę, 
zwrócił uwagę na wzrastające znaczenie słabych więzi, charakterystycznych dla współczesnych warunków życia w mieście. Zamiast więc, jak wielu innych autorów, pisać o kryzysie i upadku postawy zaangażowania $\mathrm{w}$ życie społeczne, wskazał na zupełnie nowe możliwości płynące obecnie ze współpracy opartej nie na silnych więziach z ograniczoną liczbą dobrze znanych sobie osób, ale znacznie bardziej pożądaną siecią luźnych (swobodnych) znajomości ze znacznie większą liczbą osób. Zauważył także to, że duża sieć luźnych kontaktów jest nie tylko bardziej pożądanym stanem z perspektywy jednostek, ale też prowadzi do rozwoju ekonomicznego w skali makro, ponieważ niczym nieograniczani ludzie skłonni są podejmować wszelkie pojawiające się wyzwania. Ludzi, których życie upływa w świecie słabych więzi, Florida nazwał klasą kreatywną. Pisząc o wyznawanych przez nich wartościach, wymieniał: indywidualizm, merytokrację oraz różnorodność i otwartość (por. Florida 2010: 91), a za naturalne środowisko życia dla ludzi należących do tej klasy uznał miasta (szczególnie te, w których potencjalna lista szans opatrzona była jak najmniejszą liczbą wymagań i ograniczeń). Na marginesie warto też przypomnieć postawioną sto lat wcześniej przez Thorsteina Veblena (1997) diagnozę tej części struktury społecznej, która znajdowała się na szczycie hierarchii - przypisywał on wtedy ludziom lepiej uposażonym znacznie bardziej „bierną" rolę, ograniczającą ich aktywność do prezentowania ogólnie rozpoznawalnych oznak swego bogactwa i pozycji w społeczeństwie. $W$ tamtych czasach powstrzymywanie się od pracy było, według Veblena, czytelnym sygnałem przynależności do uprzywilejowanej części społeczeństwa, podobnie jak uczestnictwo w stopniu większym niż średnia w życiu kulturalnym i artystycznym. Wśród obowiązków z kolei wymienić można opanowanie skodyfikowanego systemu skomplikowanych reguł dobrego zachowania się $\mathrm{w}$ towarzystwie. Wspomniane towarzystwo oparte było natomiast na silnych więziach społecznych, a członkostwo $\mathrm{w}$ nim związane $\mathrm{z}$ przekazywanym $\mathrm{z}$ pokolenia na pokolenie majątkiem oraz stylem życia.

Przywoływany już Florida podał przykłady migrantów przybywających do Stanów Zjednoczonych i nawiązujących tam nowe relacje społeczne (luźne) ułatwiające i umożliwiające im szybką adaptację i wykorzystywanie szans, jakie dawała nowa ojczyzna. Dla Floridy celem, do którego powinno dążyć społeczeństwo, jest właśnie dalsze nawiązywanie luźnych więzi z dużą liczbą osób, co nie będzie krępować jednostkowej kreatywności i wolności, a ponadto przyniesienie korzyści wszystkim członkom społeczeństwa. Według niego proces ten rozpoczął się wśród specjalistów różnych branż (w klasie kreatywnej) i powinien upowszechnić się w całym społeczeństwie, co jest elementem przyciągającym kolejne pokolenia migrantów 
i dowodzącym atrakcyjności słabych więzi (por. Florida 2007: 265; 2010: 31; Castles, Miller 2011: 64).

Koncepcja Floridy zyskała popularność i stała się obiektem wielu polemik. Do jej założeń odnosili się także autorzy badania realizowanego w latach 2006-2010 w Poznaniu przez zespół naukowców uczestniczących w projekcie ACRE (Accommodating Creative Knowledge. Competitiveness of European Metropolitan Regions within the Enlarged Union). Zweryfikowali oni niektóre z hipotez Floridy na gruncie europejskim, ukazując specyfikę rozwoju w naszych stronach. Przykładowo:

„Z szacunków Floridy [...] wynika, że udział pracowników sektora kreatywnego w Stanach Zjednoczonych wynosi ok. 30\% ogólnego zatrudnienia, ale aż 47\% funduszu płac, oraz że średnie wynagrodzenie tej grupy jest blisko 2-krotnie wyższe niż wynagrodzenie w sektorach produkcyjnym i usługowym" (Stryjakiewicz, Stachowiak 2010: 7).

Autorzy zauważyli, że odsetek ten dla miast europejskich różni się od powyższych szacunków, sięgając $38 \% \mathrm{w}$ przypadku rozwiniętych miast zachodnioeuropejskich i znacznie mniej w krajach naszego regionu.

$Z$ jednej więc strony, jak słusznie zauważają dalej autorzy tego raportu:

"fakt wzrostu znaczenia sektora kreatywnego w strukturze społeczno-gospodarczej wybranych regionów staje się coraz bardziej widoczny" (Stryjakiewicz, Stachowiak 2010: 8),

jednak z drugiej:

„Wyniki badań pracowników reprezentujących sektor kreatywny w europejskich ośrodkach metropolitalnych wskazują na ich stosunkowo niewielką mobilność. Aż $48 \%$ z nich mieszka i pracuje w mieście, w którym się urodziło" (Stryjakiewicz, Stachowiak 2010: 101).

Warto także dodać, że zgodnie z raportem dla Poznania odsetek ten wynosi niemal $60 \%$, co stawia go wśród miast z najniższymi wskaźnikami mobilności. Wyniki te nie potwierdzają sformułowanych przez Floridę wniosków dotyczących przypisywanej klasie kreatywnej mobilności. Stanowisko to zostało zakwestionowane $\mathrm{w}$ prezentowanych już powyżej badaniach realizowanych w ramach projektu ACRE. Autorzy raportu piszą dalej:

„Hipotezy podkreślające rolę czynników miękkich i mobilności przedstawicieli klasy twórczej w rozwoju sektora kreatywnego sprawdzają się przede wszystkim w regionach, gdzie tradycja odgrywa mniejszą rolę, a społeczeństwa są od stuleci otwarte i wielokulturowe (najlepszym przykładem jest Amsterdam)" (Stryjakiewicz, Stachowiak 2010: 127). 


\section{MIASTA (I PRZEDMIEŚCIA) JAKO CENTRA MOBILNOŚCI}

Ruchliwość jest jedną z tych kategorii, które często są traktowane jako najważniejsza kategoria do opisu współczesności. Ruchliwość dotyczy gotowości do zmiany miejsca zamieszkania (i to wielokrotnego), ale także gotowości do pokonywania znacznych odległości podczas codziennych dojazdów do pracy. Wydaje się, że nieprzerwany okres wzrostu polskiej gospodarki, mimo spowolnienia ostatnich lat, będzie się utrzymywać. Wzrost PKB w roku 2013 miał wynieść, według prognoz, 1,3\%, a w kolejnym, 2014 r. już 2,4\%. Polacy spędzają w pracy więcej czasu, niż wynosi średnia dla krajów Unii Europejskiej, a co ósmy Polak deklaruje spędzanie w pracy ponad 60 godzin tygodniowo (za: Boguszewski 2012). Wyższy od średniej unijnej jest też odsetek Polaków prowadzących własną działalność gospodarczą w 2012 r. wynosił 18,9\%, wobec 15,1\% dla całej Unii (za: Błaszczak 2013). Jednak zarówno wzrost gospodarczy, jak i ciężka praca prowadzą także do zjawisk o zróżnicowanym charakterze. Dla przykładu, według badania z 2012 r. więcej Polaków obawia się utraty pracy i bezrobocia jako zagrożenia dla swojego zdrowia psychicznego (65\%) niż „kryzysu rodziny” (46\%) (za: Boguszewski 2012).

Za szczególnie istotne dla wspomnianych powyżej przemian należy uznać procesy związane ze zmianami miejsca zamieszkania i bardzo widocznymi trendami rozwoju przedmieść kilku największych ośrodków miejskich w naszym kraju. Ostatnie lata przyniosły więc postępujący zanik obszarów niezurbanizowanych, połączony z żywiołowym (a więc zazwyczaj pozbawionym planu) rozwojem obszarów podmiejskich, jednak często bez potrzebnej infrastruktury drogowej, kanalizacyjnej etc. Wokół dużych miast powstają więc liczne podmiejskie obszary zurbanizowane, jednak ich rozwój przebiega na różne sposoby - wąskie i zatłoczone uliczki, którymi co rano mieszkańcy przedmieść próbują się dostać do miejsca pracy w mieście, a po południu wrócić do domu, są znakiem rozpoznawczym urban sprawl w wersji lokalnej. Problem jest tym większy, że samochód jest podstawowym środkiem dojazdu do pracy dla niemal połowy pracujących Polaków - według badań CBOS $43 \%$ pracujących Polaków deklaruje korzystanie z samochodu, a $20 \%$ łączy różne środki transportu publicznego (za: Boguszewski 2013). W odniesieniu do mieszkańców Poznania odsetek osób dojeżdżających do pracy samochodem wynosi 40,1\% (za: Stryjakiewicz, Męczyński 2010: 45).

Rozwój miast i specyfika życia na przedmieściach sprzyjają życiu społecznemu opartemu na słabych więziach, tak jak opisywali je wspomniani wyżej autorzy. Wynika to nie tylko z kalkulacji kosztów dojazdów do pracy 

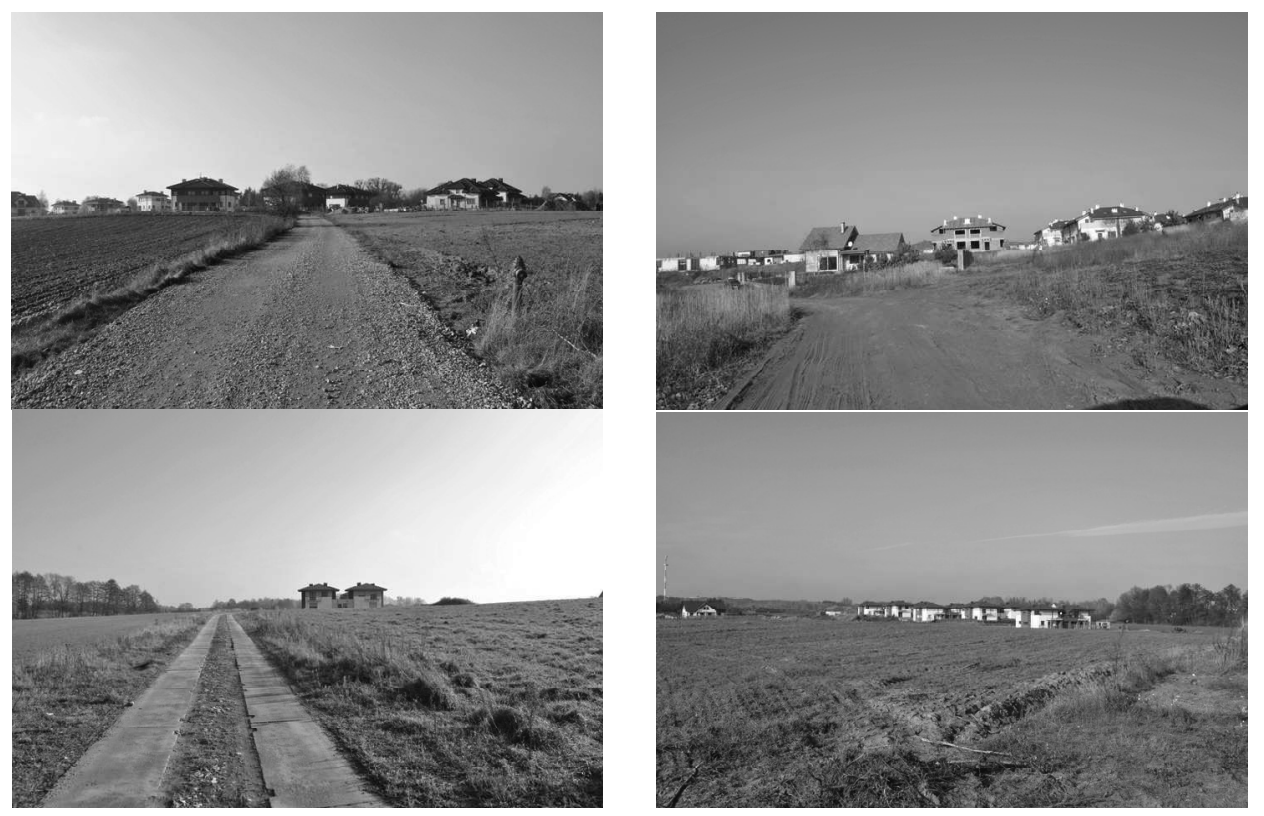

Przedmieścia Poznania - architektoniczny chaos podmiejskiej zabudowy mieszkaniowej połączony z brakami w rozbudowie infrastruktury drogowej (fot. J. Isański)

i czasu poświęcanego na nie, ale i z sąsiedztwa, w którym brakuje czasu i chęci na bliższe relacje. Prognozy dotyczące ewentualnego wzrostu liczby ludności wiejskiej dla Polski wiązane są z migracjami z miast do obszarów leżących w pobliżu wielkich miast, podczas gdy dla rozległych obszarów zachowujących wiejski charakter (warunki zamieszkania, rynek pracy) przewidywana jest „stopniowa peryferyzacja i depopulacja” (za: Dmochowska (red.) 2012: 52-54). Jak czytamy dalej $w$ tym raporcie:

„W wyżej wymienionych funkcjonalnych obszarach miejskich można dostrzec trwający i już wyraźnie zaawansowany proces przenoszenia z centrum na obszary pozamiejskie zarówno mieszkańców i miejskiego stylu życia, jak i niektórych funkcji miejskich. Coraz większa ich liczba podejmuje decyzje o zmianie miejsca zamieszkania w celu poprawy komfortu życia przy zachowaniu w miarę łatwego dostępu do miejsca zatrudnienia i do różnego rodzaju usług specyficznych dla dużego miasta" (Dmochowska (red.) 2012: 54).

Wśród wymienianych $\mathrm{w}$ cytowanym raporcie najważniejszych cech rozwoju miast przechodzących postsocjalistyczną transformację wymieniane są m.in.: "dezindustrializacja gospodarki miejskiej powiązana z rozwojem sektora usług", "odrodzenie samorządów lokalnych i zmiana charakteru 
planowania urbanistycznego", "spadek znaczenia sektora publicznego na rzecz sektora prywatnego", a także "próby gentryfikacji i rewitalizacji starej zabudowy mieszkaniowej” oraz „zastąpienie migracji z obszarów wiejskich do miast przez migrację z miast na obszary wiejskie" (za: Stryjakiewicz i in. 2010: 29).

Ostatnie lata przyniosły także zmianę $\mathrm{w}$ postrzeganiu miejsca pracy i czasu poświęcanego na codzienne dojazdy oraz skłonności do zmiany miejsca zamieszkania związaną ze zmianą miejsca pracy. Dynamikę tej zmiany obrazują dane z badań ogólnopolskich realizowanych przez CBOS w 2012 r. Według tych danych pomiędzy rokiem 2009 a 2013 w Polsce wzrósł odsetek osób skłonnych dojeżdżać do innej miejscowości, „by zmienić pracę na lepszą lub ją tam dostać" z 53\% do 61\%, wyjechać do pracy za granicę - z $26 \%$ do $32 \%$, czy też przeprowadzić się do innej miejscowości z $28 \%$ do $31 \%$. Należy także wspomnieć, iż zdecydowana większość przeprowadzek, które już się odbyły, ma ograniczony zasięg - 71\% Polaków, którzy przeprowadzali się $\mathrm{w}$ swoim dorosłym życiu, czyniło to $\mathrm{w}$ obrębie województwa, przy czym większość tych przeprowadzek dotyczyła odległości mniejszej niż $50 \mathrm{~km}$ od dotychczasowego miejsca zamieszkania (za: Kowalczuk 2010). Autorka tego raportu pisze także o zmianie migracyjnych preferencji Polaków w ostatnich latach - wśród pożądanych miejsc zamieszkania coraz więcej zwolenników zyskują "duże miasta" (30\% odpowiedzi, wobec 23\% w 1996 r.) oraz „wieś" (przyciągająca uwagę 28\% respondentów, wobec 17\% w 1996 r.; wszystkie dane za: Kowalczuk 2010), ubywa natomiast osób zainteresowanych zamieszkaniem $\mathrm{w}$ małych i średnich miejscowościach co, zdaniem autorki raportu, dowodzi zmiany związanej z postrzeganiem mniejszych ośrodków miejskich jako oferujących, zwłaszcza ludziom młodym, ograniczone możliwości rozwoju i samorealizacji.

Z raportu Głównego Urzędu Statystycznego z 2012 r. możemy dowiedzieć się o skali rozwoju miast i leżących wokół nich tzw. obszarów metropolitalnych. W przykładzie Poznania jak w soczewce skupiają się pozytywne konsekwencje rozwoju w ostatnich latach - rośnie liczba zagranicznych inwestycji, bezrobocie utrzymuje się na niskim poziomie, a miastu każdego roku przybywa mieszkańców przyjeżdżających z mniejszej lub większej odległości. Wielu z nich jednak nie zamieszkuje w mieście na stałe, decydując się w zamian na poszukiwanie tańszego miejsca do zamieszkania w którejś z podmiejskich gmin. Dla przykładu, liczba ludności w podpoznańskich gminach w latach 2001-2010 wzrosła następująco: w gminie Dopiewo o $68,7 \%$, Komorniki o $66,4 \%$, Rokietnica o $60,4 \%$, Kórnik o $54,7 \%$, Swarzędz o 53,3\%, Suchy Las o 49,4\%, Tarnowo Podgórne o 35,3\%, Kleszczewo o 34,6\% (za: Dmochowska 2012: 54-60). Dla całego tzw. Funkcjonalnego 
Obszaru Miejskiego w przypadku Poznania wzrostowi liczby ludności towarzyszył także spadek liczby ludności zamieszkującej miasto. Jak piszą autorzy raportu, opuszczający miasto poszukują zalet życia na wsi przy zachowaniu dochodów z pracy w mieście. Trend ten, w skali całego kraju, przyniósł odpływ ludności mieszkającej w miastach o niemal 400 tys. i zwiększenie liczby mieszkańców wsi o 340 tys. (za: Dmochowska 2012: 48). W 2012 r. wydano w Polsce ponad 57 tys. pozwoleń na budowę domów indywidualnych, a w 2013 r. już 59,8 tys. (za: Informacja o sytuacji... 2013). Wzrostowi liczby ludności wsi towarzyszy także zmiana charakteru społecznego obszarów wiejskich: w 2013 r. 8\% mieszkańców wsi deklarowało pochodzenie z miasta, a jedynie $18 \%$ mieszkających na wsi podawało rolnictwo jako źródło utrzymania (za: Hipsz 2013). Różnice widoczne są nie tylko w źródłach utrzymania, ale i w stylach życia: "czytanie książki dla przyjemności” w dwunastu miesiącach poprzedzających badanie deklaruje $44 \%$ mieszkańców wsi, wobec $71 \%$ tych, którzy przeprowadzili się tam z miasta; wizytę $\mathrm{w}$ teatrze, odpowiednio, $6 \%$ i $21 \%$, a wyjazd na co najmniej tygodniowy urlop $19 \%$ urodzonych na wsi, wobec $33 \%$ tych, którzy wprowadzili się tam niedawno (za: Hipsz 2013). Jakie inne zmiany dają się zaobserwować w Poznaniu i na jego przedmieściach? Autorzy wspomnianego już raportu podsumowują:

„O zamieszkaniu pracowników sektora kreatywnego w POM [Poznański Obszar Metropolitalny - dop. J.I.] decydowały głównie czynniki twarde, w szczególności związane z rynkiem pracy. Zaznacza się również relatywnie duże znaczenie czynników miękkich związanych z jakością życia" (Stryjakiewicz, Męczyński 2010: 54).

Zmiany na rynku pracy przyniosły więc także zmianę oczekiwań dotyczących miejsca zamieszkania, standardu warunków życia, preferencji związanych $\mathrm{z}$ dostępnymi formami spędzania wolnego czasu, a ponadto zacieranie się różnic pomiędzy stylem życia w mieście i na wsi.

Przemiany zachodzące $\mathrm{w}$ społeczeństwie polskim $\mathrm{w}$ ostatnich latach przyniosły zupełnie nowe możliwości rozwoju zawodowego, przyczyniły się do modyfikacji reguł życia społecznego, a także przyspieszyły migracyjne procesy zachodzące zarówno w skali międzynarodowej, jak i lokalnej. Jak pokazują wyniki wielu badań nad migracjami, ruchy ludności zachodzące wewnątrz krajów są bardzo często jedynie pierwszym etapem przed wyjazdem za granicę.

Pełniejsze dane dotyczące motywacji Polaków i ich rozumienia życiowego sukcesu znaleźć można w raporcie z badań CBOS z 2013 r., w którym "warunki materialne" uznawane są za element życiowego sukcesu przez $18 \%$ respondentów, o ile łączą się z "dobrą pracą" i „dobrą rodziną", pod- 
czas gdy same "dobre warunki materialne” uznawane są za ważne jedynie przez 7\% pytanych (za: Orlińska 2013, 2-4). Wydaje się, że jednym z najważniejszych wskaźników jest miejsce zamieszkania, będące kombinacją informacji o statusie społecznym i udanym życiu rodzinnym.

\section{ZAKOŃCZENIE}

Dziesiąta rocznica przystąpienia Polski do Unii Europejskiej wymaga także odpowiedzi na pytanie, czy powyższe informacje o skali ruchliwości przestrzennej Polaków nie zwiastują dalszego nasilania się migracji międzynarodowych. Wątpliwości te pojawiają się coraz częściej w publicznym dyskursie. Migrantów, którzy w ostatnich latach wyjechali z Polski, liczy się w milionach. Ponadto, jak prognozują na przykład eksperci Instytutu Sobieskiego, migranci zagraniczni "zbudują dobrobyt Europy Zachodniej”, ale zabraknie ich w polskiej gospodarce w najbliższych latach. Dodatkowo bardzo niskie wskaźniki dzietności w Polsce rysują pesymistyczny scenariusz długoterminowych przemian, zwłaszcza jeśli do informacji o zmniejszającej się populacji dodać także tę o jej starzeniu się. Pytania, które można w związku z tym zadać na koniec niniejszych rozważań, dotyczą przyszłości. Czy przyniesie ona nasilenie procesów urbanizacji obszarów podmiejskich? A w migracjach międzynarodowych - czy uda się zatrzymać odpływ ludności na Zachód? Warto pamiętać, że ze względu na specyfikę migracji sezonowych, wahadłowych, niesłychanie trudno jest określić liczbę tych, którzy już wyjechali. Czy w przyszłości będzie ich więcej? A może Polsce uda się przyciągnąć członków globalnej klasy kreatywnej z krajów, których potencjał dopiero czeka na wykorzystanie - czy to z krajów sąsiadujących z Polską czy też z bardziej odległych rejonów? Jakie będą kierunki migracji, zwłaszcza wewnątrzkrajowych? Czy postępujący rozwój technologiczny przybliży nas do stanu, w którym przestrzeń i jej ograniczenia przestaną wyznaczać granice rozwoju?

\section{BIBLIOGRAFIA}

Błaszczak A. (2013), Nomadzi XXI wieku, „Rzeczpospolita” 16-17.03.2013.

Boguszewski R. (2012), Zdrowie psychiczne Polaków, cbos.pl, BS/132/2013 [dostęp: czerwiec 2014].

Boguszewski R. (2013), Mobilność i elastyczność zawodowa Polaków, cbos.pl, BS/11/2013 [dostęp: czerwiec 2014].

Castles S., Miller M.J. (2011), Migracje we wspótczesnym świecie, Wydawnictwo Naukowe PWN, Warszawa. 
Dmochowska H., red. (2012), Miasta w liczbach 2010, raport z badań Głównego Urzędu Statystycznego, Urząd Statystyczny w Poznaniu, stat.gov.pl [dostęp: czerwiec 2014].

Dziedzina J. (2013), Emigranci nie wróca, wywiad z prof. Krystyną Iglicką-Okólską, „Gość Niedzielny" nr 45, rok XC.

Florida R. (2007), The Flight of the Creative Class, Macmillan, Basingstoke.

Florida R. (2010), Narodziny klasy kreatywnej oraz jej wptyw na przeobrażenia w charakterze pracy, wypoczynku, społeczeństwa i życia codziennego, Narodowe Centrum Kultury, Warszawa.

Hipsz N. (2013), Wieś polska - rdzenni i nowi mieszkańcy, cbos.pl, BS/120/2013 [dostęp: czerwiec 2014].

Informacja o sytuacji społeczno-gospodarczej Polski w okresie I-III kwartał 2013 r., 22.10. 2013 r., Departament Analiz i Opracowań Zbiorczych, GUS, Warszawa.

Kobeszko J. (2013), Zbudujemy gospodarki Wielkiej Brytanii i Niemiec, Instytut Sobieskiego, www.sobieski.org.pl [dostęp: czerwiec 2014].

Kowalczuk K. (2010), Mobilność i preferencje migracyjne Polaków, cbos.pl, BS/26/2010 [dostęp: czerwiec 2014].

Kowalczuk K. (2012), Mobilność na co dzień, cbos.pl, BS/104/2012 [dostęp: czerwiec 2014].

Orlińska J. (2013), Sukces życiowy i jego determinanty, cbos.pl, BS/89/2013 [dostęp: czerwiec 2014].

Pobłocki K. (2013), Nikt już nie tęskni do wsi, „Rzeczpospolita” 12-13.10.2013.

Riesman D., Glazer N., Denney R. (1996), Samotny ttum, Wydawnictwo Muza, Warszawa.

Simmel G. (2005), Socjologia, Wydawnictwo Naukowe PWN, Warszawa.

Stryjakiewicz T., Kaczmarek T., Męczyński M., Parysek J.J., Stachowiak K. (2010), Sektor kreatywny w poznańskim obszarze metropolitalnym, t. III: Polityka wspierania rozwoju sektora kreatywnego w poznańskim obszarze metropolitalnym na tle doświadczeń zagranicznych, Bogucki Wydawnictwo Naukowe, Poznań.

Stryjakiewicz T., Męczyński M. (2010), Sektor kreatywny w poznańskim obszarze metropolitalnym, t. II: Atrakcyjność poznańskiego obszaru metropolitalnego dla pracujących w sektorze kreatywnym, Bogucki Wydawnictwo Naukowe, Poznań.

Stryjakiewicz T., Stachowiak K. (2010), Sektor kreatywny w poznańskim obszarze metropolitalnym, t. I: Uwarunkowania, poziom i dynamika rozwoju sektora kreatywnego w poznańskim obszarze metropolitalnym, Bogucki Wydawnictwo Naukowe, Poznań.

Veblen T. (1997), Teoria klasy próżniaczej, Wydawnictwo Muza, Warszawa.

Wirth L. (1927), The Ghetto, „The American Journal of Sociology” vol. 33, no. 1. 